Western North American Naturalist 68(1), (C) 2008, pp. 83-102

\title{
GEOGRAPHIC PATTERNS OF GROUND-DWELLING ARTHROPODS ACROSS AN ECOREGIONAL TRANSITION IN THE NORTH AMERICAN SOUTHWEST
}

\author{
David C. Lightfoot ${ }^{1,3}$, Sandra L. Brantley ${ }^{1}$, and Craig D. Allen ${ }^{2}$
}

\begin{abstract}
We examined the biogeographic patterns of ground-dwelling arthropod communities across a heterogeneous semiarid region of the Southern Rio Grande Rift Valley of New Mexico. Our 3 sites included portions of 5 ecoregions, with the middle site a transition area where all ecoregions converged. We addressed the following 3 questions: (1) Do the species assemblage patterns for ground arthropods across habitats and sites conform to recognized ecoregions? (2) Are arthropod assemblages in distinct vegetation-defined habitats within an ecoregion more similar to each other or to assemblages in similar vegetation-defined habitats in other ecoregions? (3) Is there a detectable edge effect with increased arthropod diversity in the area of converging ecoregions? We encountered 442 target arthropod species from pitfall traps operating continuously for 7 years over a series of different habitats at each of the 3 sites. We examined geographic distributions of spider and cricket/grasshopper species in detail, and they showed affinities for different ecoregions, respectively. Each habitat within a study site supported a unique overall arthropod assemblage; nevertheless, different habitats at the same site were more similar to each other than they were to similar habitats at other sites. Overall arthropod species richness was greatest in the area where all 5 ecoregions converged. Arthropod species and their geographic distributions are poorly known relative to vascular plants and vertebrate animals. Findings from this research indicate that ecoregional classification is a useful tool for understanding biogeographic patterns among arthropods.
\end{abstract}

Key words: biome transition, crickets, diversity, ecoregion, ecotone, edge effect, grasshoppers, insects, species, spiders.

Geographic distribution patterns of plant and animal species result from multiple factors, including proximity to historical and evolutionary source areas, climate, distribution and availability of environmental resources, and biotic interactions (Ricklefs and Schluter 1993, Brown and Lomolino 1998, Lomolino and Heaney 2004). Much is known about the geographic distribution and diversity patterns of vascular plants and vertebrate animals, however, relatively little is known about the geographic patterns and processes accounting for the distributions of most terrestrial invertebrates (Parmenter et al. 1995, Ricketts et al. 1999). One of the goals of our research was to provide much-needed information on the distribution and abundance patterns of terrestrial arthropods.

At the continental scale, conceptual biomes (Whittaker 1975, Ricklefs and Miller 2000), or more finely delineated ecoregions (e.g., Ricketts et al. 1999), are biogeographic areas with similar climates, landscapes, and biotic assemblages that are more similar to each other than to those in adjacent ecoregions. The association of species with biogeographic regions includes abiotic factors (especially climate) and biotic factors such as plant-animal and predator-prey interactions (Shmida and Wilson 1985, Brown 1995). Species richness is expected to increase at ecotones (edge effect of Odum 1971, Holland et al. 1991, Risser 1993, 1995), the areas where different regional assemblages converge. The extent of species overlap depends on individual species' distributions, the number and steepness of environmental gradients, and the number of converging biogeographic regions.

The American Southwest is geologically young, with a flora and fauna that developed mostly during the Quaternary Period (Axelrod 1958, Van Devender and Spaulding 1983, Van Devender 1995). The area supports some of the most topographically (Hunt 1983) and biologically diverse semiarid temperate landscapes in the world (Brown 1982, Parmenter et al. 1995), ranging from hot, dry lowland deserts to cool, moist montane forests. Within the Southwest, several continental ecoregions (Ricketts et al. 1999) converge across the Southern Rio Grande Rift Valley that bisects New Mexico from north

\footnotetext{
${ }^{1}$ Museum of Southwestern Biology, University of New Mexico, Albuquerque, NM 87131.

2United States Geological Survey, Biological Resources Discipline, Jemez Mountains Field Station, Los Alamos, NM 87544

3E-mail: dlightfo@unm.edu
} 


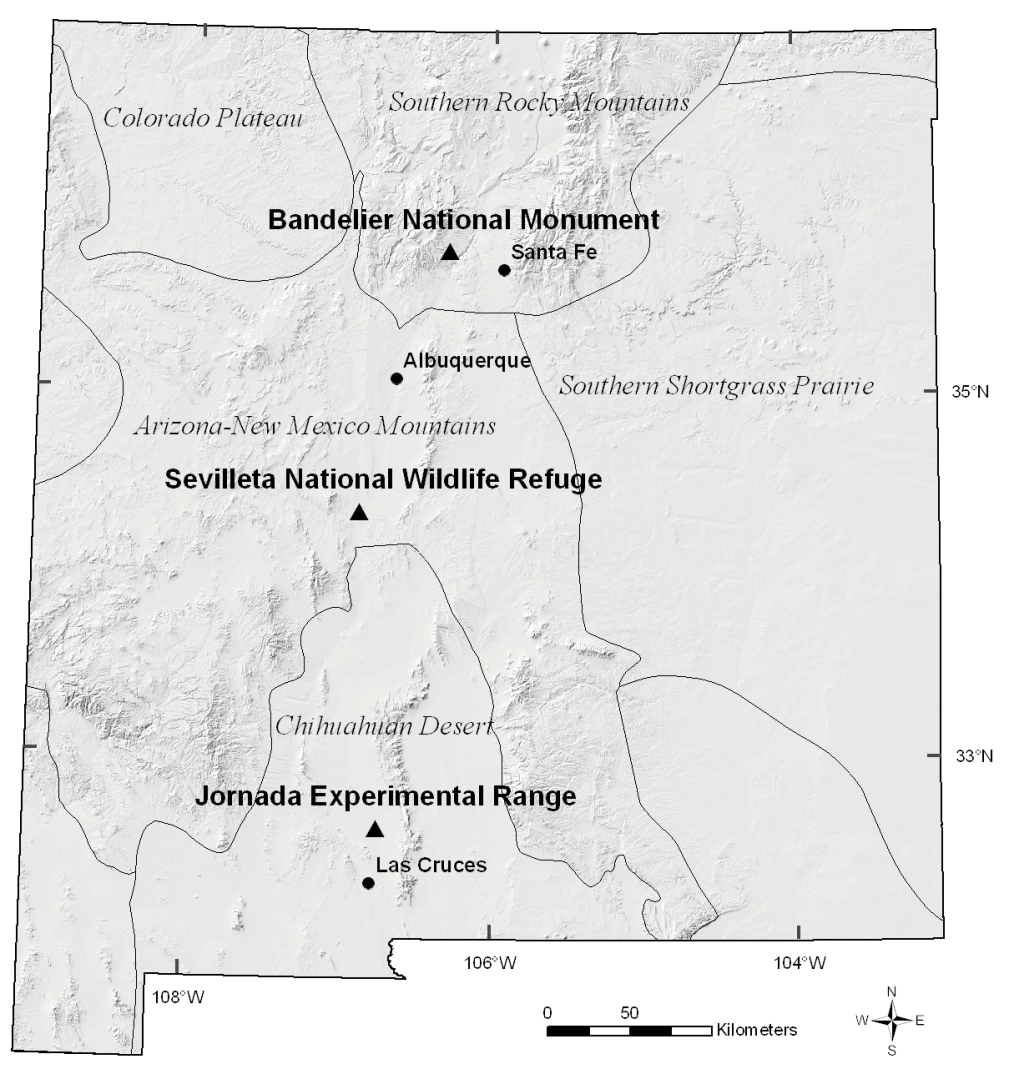

Fig. 1. Map of the study area and ecoregion boundaries.

to south (Hawley 1978): forests of the Southern Rocky Mountains (sensu current Nature Conservancy / World Wildlife Fund designation) and forests of the Arizona-New Mexico Mountains (sensu current Nature Conservancy / World Wildlife Fund designation) occupy the high elevations; and the Colorado Plateau, the Chihuahuan Desert, and the Western Short Grasslands (Southern Shortgrass Prairie, sensu current Nature Conservancy / World Wildlife Fund designation) all converge in the lowlands (Fig. 1). Additionally, the Southern Rio Grande Rift Valley spans the convergence of 3 geographically higher-ranking bioregions: eastern North America to the east, northern Mexico to the south, and western North America to the north (Ricketts et al. 1999).

The goal of this study was to assess geographic patterns of arthropod communities associated with landscapes across this area of ecoregion transitions. We focused on grounddwelling arthropods, which have important roles in semiarid systems as detritivores, her- bivores, and predators (Crawford 1981, Whitford 1986, Polis 1991). To better understand the biogeography of these arthropods, we addressed the following questions: (1) What are the species assemblage patterns for ground arthropods across the study sites and across within-site habitats, and do they conform to recognized ecoregions (sensu Ricketts et al. 1999)? (2) Are arthropod assemblages in distinct vegetation-defined habitats within an ecoregion more similar to each other than to assemblages in similar vegetation-defined habitats in other ecoregions? (3) Are there detectable edge effects (Odum 1971) for increased arthropod diversity in the transition area of converging ecoregions?

\section{Methods}

\section{Study Sites}

This study was conducted at 3 sites located along the Southern Rio Grande Rift Valley in New Mexico (Fig. 1). A series of 3-4 local 

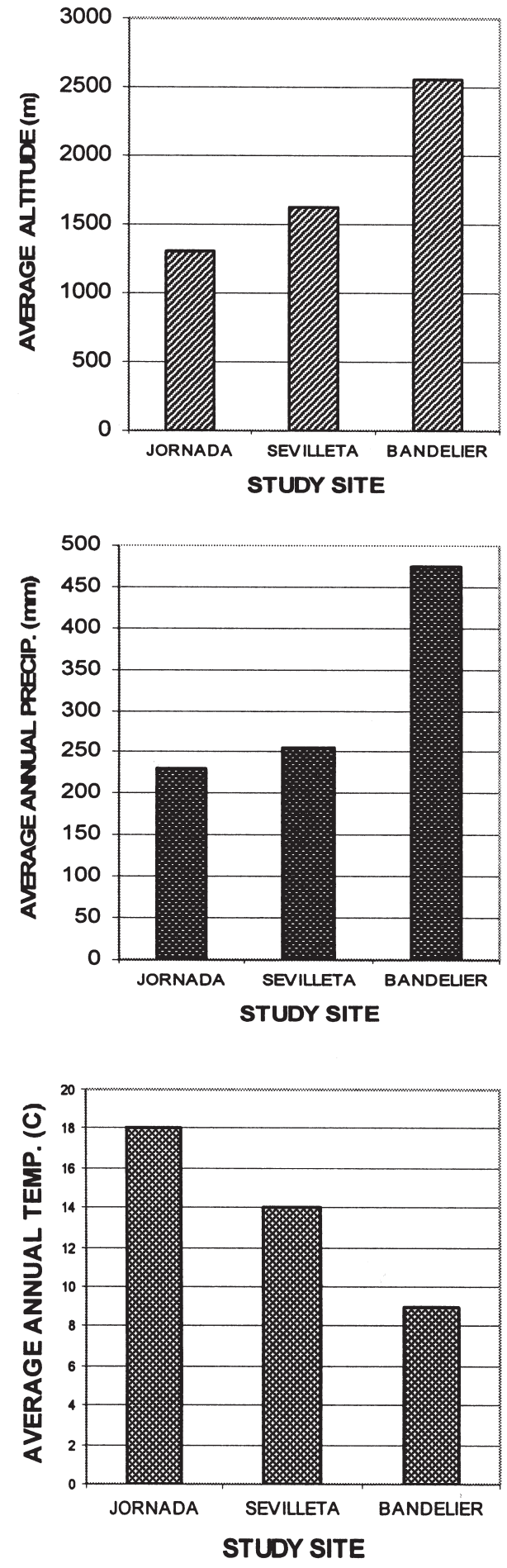

Fig. 2. Average elevations ( $\mathrm{m}$ asl) (a), long-term average annual precipitation (b); and long-term average daily ambient temperatures (c) from each of the 3 principal study sites. habitats recognized on the basis of plant community classifications (Dick-Peddie 1993) were sampled within each study site, for a total of 10 habitat samples across a biogeographic transition region from the Chihuahuan Desert to the south, the Southern Rocky Mountains to the north, the Arizona-New Mexico Mountains and Colorado Plateau to the west, and the Southern Shortgrass Prairie to the east (Ricketts et al. 1999; Fig. 1). Dick-Peddie (1993) and Brown (1982) provide detailed hierarchical vegetation classifications for the floristic and environmental characteristics of this region.

The 3 study sites were associated with 3 different long-term ecological research programs: the National Science Foundation (NSF)funded Jornada Basin Long-Term Ecological Research (LTER) program, the NSF Sevilleta LTER program, and the United States Geological Survey, Jemez Mountains Field Station. The habitats used for this study were representative of the ecoregions listed above and were the dominant environments across each of the 3 research sites.

The Chihuahuan Desert ecoregion (Ricketts et al. 1999), consisting of Chihuahuan Desert scrub and desert grassland communities (DickPeddie 1993) in the southern Rio Grande valley of New Mexico, was represented by 4 habitats in the Jornada Basin (JRN) in south central New Mexico: (1) mesquite (Prosopis glandulosa) sand dune fields, $1330 \mathrm{~m}, 32^{\circ} 33^{\prime} 0^{\prime \prime} \mathrm{N}$, $106^{\circ} 42^{\prime} 39^{\prime \prime} \mathrm{W}$ (datum NAD27 for all coordinates); (2) tarbush (Flourensia cernua) basin floor, $1315 \mathrm{~m}, 32^{\circ} 37^{\prime} 09^{\prime \prime} \mathrm{N}, 106^{\circ} 47^{\prime} 13^{\prime \prime} \mathrm{W}$; (3) creosotebush (Larrea tridentata) piedmont slopes, $1355 \mathrm{~m}, 32^{\circ} 40^{\prime} 04^{\prime \prime} \mathrm{N}, 106^{\circ} 46^{\prime} 12^{\prime \prime} \mathrm{W}$; and (4) black grama (Bouteloua eriopoda) grassland, $1318 \mathrm{~m}, 32^{\circ} 29^{\prime} 22^{\prime \prime} \mathrm{N}, 106^{\circ} 46^{\prime} 47^{\prime \prime} \mathrm{W}$.

The Sevilleta National Wildlife Refuge (SEV) in the central Rio Grande valley of New Mexico was geographically centered between the JRN to the south and Bandelier (see below) to the north. The SEV also represented a region of multiple ecoregional transitions from the north, south, east, and west. The SEV was located within the Arizona-New Mexico Mountains ecoregion, yet the lowland environments contained flora characteristic of the surrounding low-elevation Chihuahuan Desert and the Southern Shortgrass Prairie ecoregions. We sampled 3 principal habitats at the SEV: (1) creosotebush piedmont (Chihuahuan Desert ecoregion; Ricketts et al. 1999), 1615 m, 


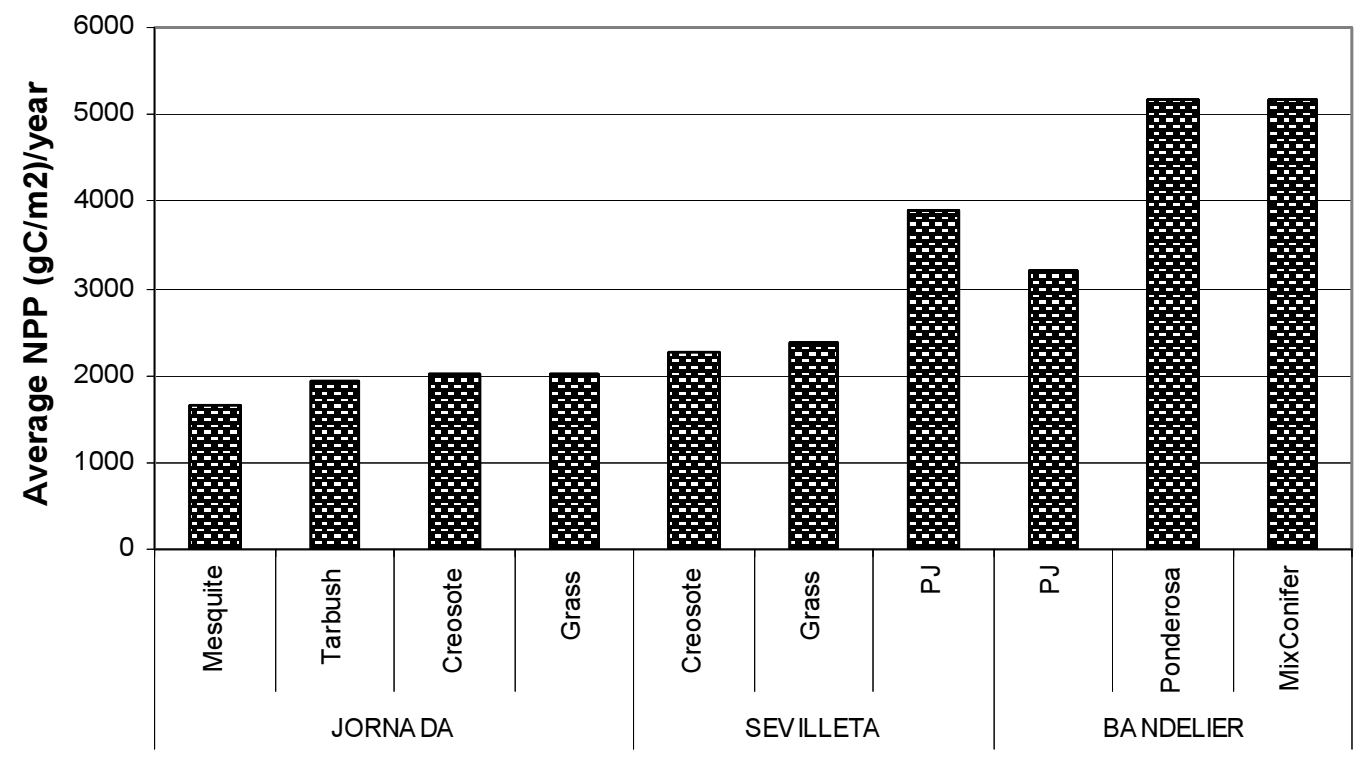

Site / Habitat

Fig. 3. Average annual net primary production among study sites and habitats estimated from MODIS remote sensing data, averaged over the years 2000-2002.

$34^{\circ} 19^{\prime} 59.0^{\prime \prime} \mathrm{N}, 106^{\circ} 44^{\prime} 9^{\prime \prime} \mathrm{W}$; (2) black grama grassland (Chihuahuan Desert ecoregion) mixed with some blue grama (Bouteloua gracilis; Southern Shortgrass Prairie and Colorado Plateau), $1616 \mathrm{~m}, 34^{\circ} 20^{\prime} 17.0^{\prime \prime} \mathrm{N}, 106^{\circ} 43^{\prime} 3^{\prime \prime} \mathrm{W}$; and (3) pinyon-juniper (Pinus edulis and Juniperus monosperma, respectively) woodland (Arizona-New Mexico Mountains forest ecoregion), $1976 \mathrm{~m}, 34^{\circ} 22^{\prime} 6.3^{\prime \prime} \mathrm{N}, 106^{\circ} 32^{\prime} 6^{\prime \prime} \mathrm{W}$.

Three habitats at Bandelier National Monument $(\mathrm{BNM})$ in the Jemez Mountains at the north end of the Southern Rio Grande Rift valley represented higher-elevation ecoregions and formed an elevational gradient: (1) pinyonjuniper woodland (Arizona-New Mexico Mountains forest ecoregion), $1948 \mathrm{~m}, 35^{\circ} 49^{\prime} 47^{\prime \prime} \mathrm{N}$, $106^{\circ} 22^{\prime} 4^{\prime \prime} \mathrm{W}$, with variable densities of pinyon $(P$. edulis) and juniper trees (J. monosperma); (2) ponderosa pine (Pinus ponderosa) forest (Arizona-New Mexico Mountains forest ecoregion), $2454 \mathrm{~m}, 35^{\circ} 45^{\prime} 45^{\prime \prime} \mathrm{N}, 106^{\circ} 15^{\prime} 52^{\prime \prime} \mathrm{W}$, with moderate to open conifer canopies; and (3) montane mixed conifer forest (P. ponderosa, Pseudotsuga menziesii, Pinus strobiformis, Abies concolor, Populus tremuloides; Southern Rocky Mountains forest ecoregion), $2712 \mathrm{~m}, 35^{\circ} 51^{\prime} 6^{\prime \prime} \mathrm{N}$, $106^{\circ} 24^{\prime} 41^{\prime \prime} \mathrm{W}$, with dense conifer canopy.

Elevation and long-term average precipitation increased from JRN to BNM (Fig. 2a-b), but long-term average annual ambient temperatures decreased (Fig. 2c). We used moderate resolution imaging spectroradiometer (MODIS) remotely-sensed data (Zhao et al. 2005, Zhao and Running 2006) averaged from 2000 to 2002 to estimate aboveground plant net primary production (ANPP; a 1-km pixel centered on pitfall traps within each habitat type per site). Plant productivity at JRN was consistently lower than at SEV or BNM; estimated ANPP values were highest at BNM (Fig. 3)

\section{Arthropods}

Ground arthropods were sampled from pitfall traps (Southwood 1966, Digweed et al. 1995, Ward et al. 2001, Woodcock 2005) consisting of small plastic cups $(7.5 \mathrm{~cm}$ top diameter $\times 10 \mathrm{~cm}$ deep, 0.25 -L volume) placed inside small steel cans $(7.5 \mathrm{~cm}$ top diameter $\times 10 \mathrm{~cm}$ deep) that were dug into the ground until the top of the can was level with the soil surface. Propylene glycol was used as the preservative, and tile covers (or local rocks at BNM where elk [Cervus elaphus] were attracted to artificial covers) protected the samples from weather. Replicate lines of traps ( 3 at JRN, 5 at SEV, and 5 at BNM) 30-50 m long were placed in each habitat type at each study site. Arthropod species richness and arthropod 

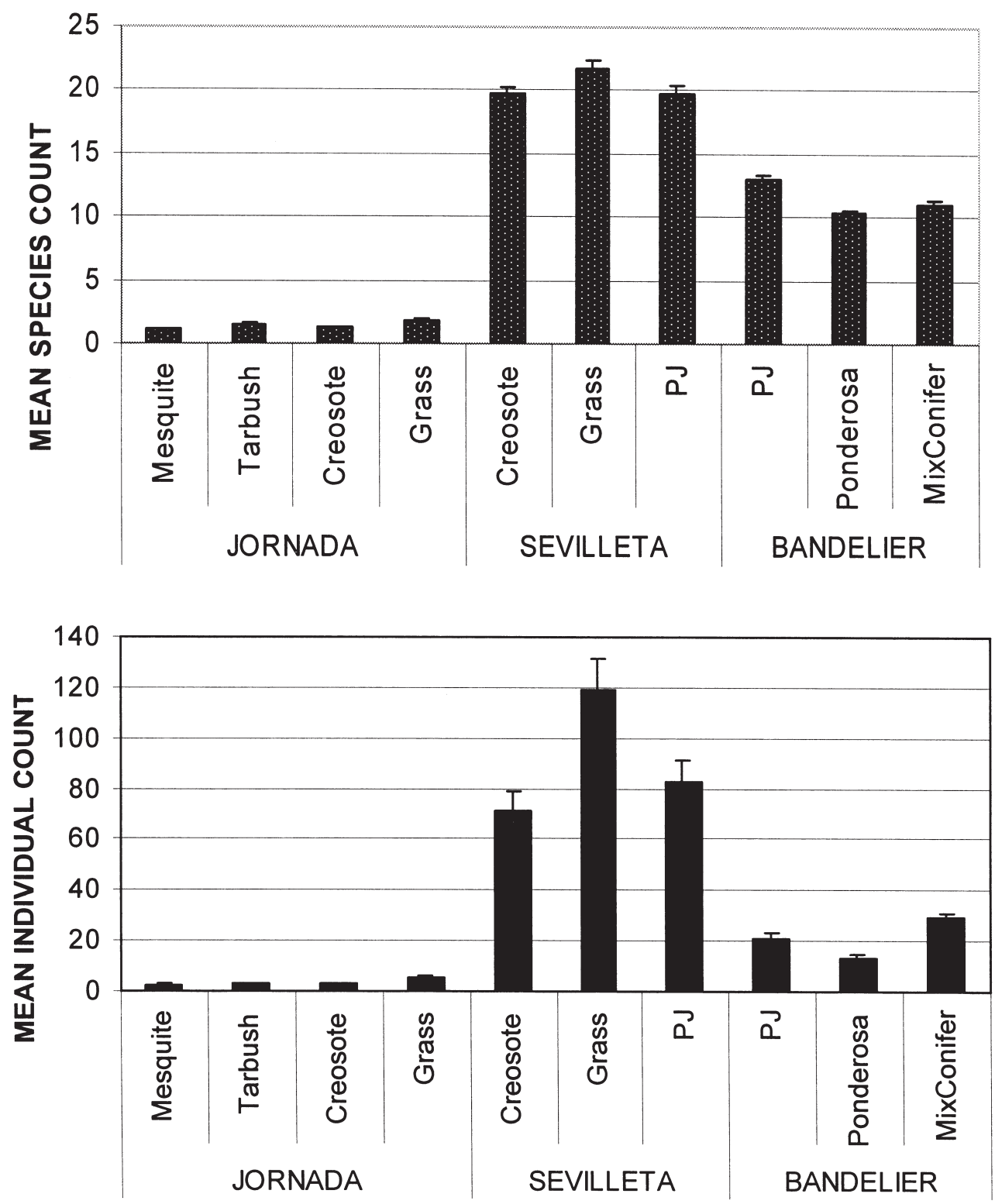

Fig. 4. Ground arthropod species richness among different habitats across the 3 principal study sites (a). Ground arthropod abundance across different habitats across the 3 principal study sites (b). Values are means per trap per replicate plot per year, with 1 standard error, over a 7-year period (1996-2002).

abundance were averaged over all traps by habitat. Trap line locations were subjectively chosen to represent a range of environments within each habitat type. Traps were left open continuously and arthropods were collected every 2 months from 1996 to 2002. Trap lines within habitats were located within $10 \mathrm{~km}$ of each other, and all habitat types within a study site were no more than $20 \mathrm{~km}$ apart.
Target taxa (i.e., taxa that we studied) included only those arthropods that are known to live primarily on the ground and that are appropriately sampled by pitfall traps (Uetz and Unzicker 1976, Thomas and Sleeper 1977, Adis 1979): spiders (4 families), bristletails (1 family), crickets (3 families), grasshoppers (2 families), true bugs ( 2 families), and beetles (4 families), as well as scorpions, sun spiders, centipedes, and 

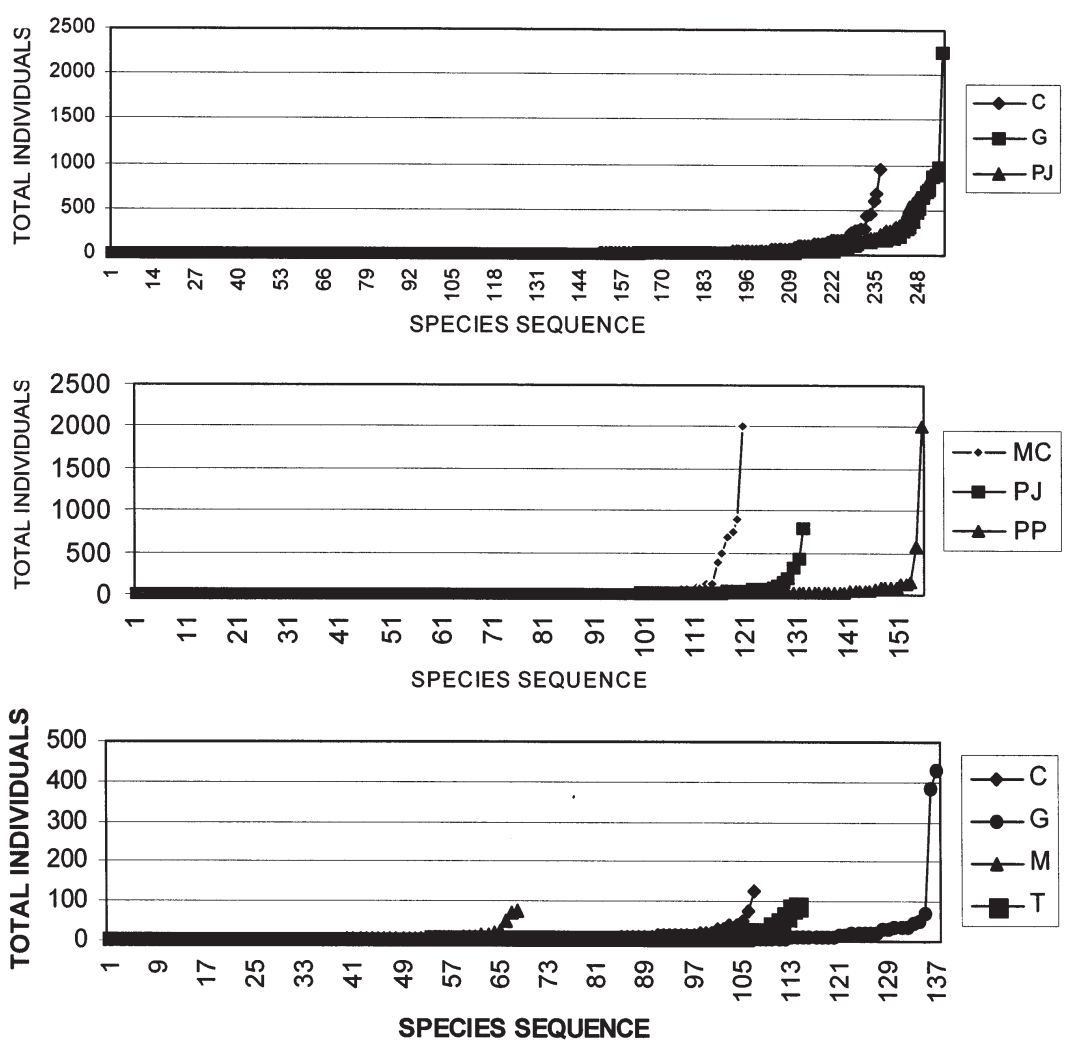

Fig. 5. Species richness and abundance curves for ground arthropods from the Sevilleta (a), Bandelier (b), and Jornada (c) habitats from 1996 to 2002.

millipedes (see Appendix 1 for scientific names of classes, orders, and families). Taxonomic classification followed Arnett (2000) for ranks from the class to the subfamily level and Poole and Gentili (2003) for genera and species. We used published distribution information to analyze patterns of grasshoppers/crickets and spiders in detail (Appendix 2). Two of us were specialists on the taxonomy, biogeography, and ecology of grasshoppers (D.C. Lightfoot) and spiders (S.L. Brantley) relative to other arthropod groups. Voucher specimens representing all target taxa were deposited in the Museum of Southwestern Biology, Division of Arthropods, University of New Mexico, Albuquerque.

\section{Data Analysis}

Multivariate and univariate data analyses were performed with PC SAS (Statistical Analysis Systems, v. 8.2; SAS Institute, Inc. 2003) software. We used nonparametric agglomerative hierarchical unweighted pair-group average cluster analysis (SAS, PROC CLUS) as a descriptive method to examine similarities of arthropod species assemblages among and within habitats, based on Euclidean distance as a measure of the similarity of species composition between habitats and sites. Only species that were represented by 10 or more observations over the entire study period were included in that analysis, thereby emphasizing only relatively common or important taxa, not rare species that may not have been adequately sampled. We used log-transformed count data for canonical discriminant function analysis (CDFA; SAS, PROC CANDISC) to test the hypothesis of no spatial differences among site habitats based on arthropod taxa/ trophic groups (i.e., the family-level ranks listed above), and to provide ordinations of habitats within sites based on arthropod composition. Large numbers of species encountered and unequal sample variances associated with various species counts (see results section, Fig. $4 \mathrm{a}-\mathrm{c})$ precluded us from using CDFA with species-level data. 


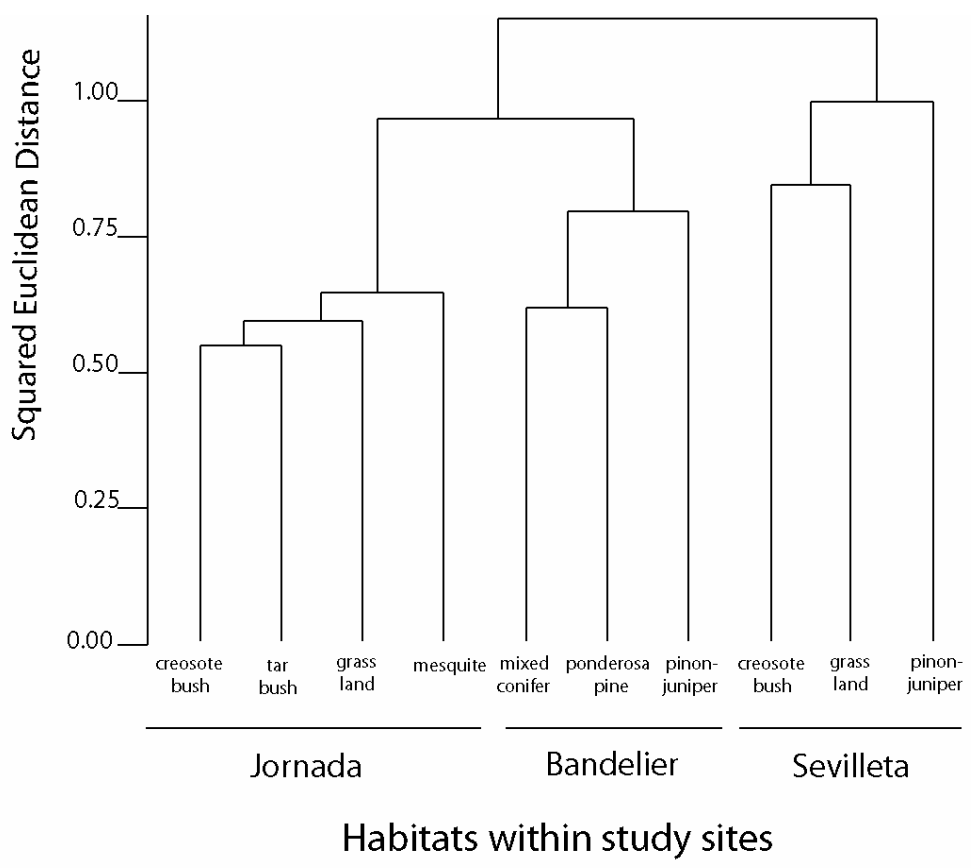

Fig. 6. Cluster analysis dendrogram of the different habitats from the 3 study sites based on ground arthropod species composition. Group average linkage method scaled by squared Euclidean distance. Habitat codes: con = mixed conifer, cre $=$ creosotebush, gra $=$ grassland, mes $=$ mesquite, $\mathrm{pnj}=$ pinyon-juniper, pon $=$ ponderosa pine .

\section{RESUlTS}

\section{Species Diversity Patterns of Ground Arthropod Assemblages}

We encountered a total of 442 target taxa across the 3 study sites over the 7-year period (Appendix 1). The greatest species richness was at SEV with 306 species, followed by BNM with 190 species and JRN with 144 species.

The greatest species richness was at the SEV black grama grassland followed by the SEV pinyon-juniper woodland and creosotebush habitats (Fig. 4a). The SEV grassland had the highest species richness and highest overall abundance of individuals (Fig. 5a). Species richness among BNM montane habitats was lowest at the high-elevation montane mixed conifer and midelevation ponderosa pine forests, and greatest at the low-elevation pinyon-juniper woodland habitat (Figs. 4a, 5b). Species richness across the 4 JRN Chihuahuan Desert habitats was greatest in the black grama grassland, followed by the tarbush, creosotebush, and mesquite sand dune habitats, respectively (Figs. $4 a, 5 c)$.

Abundance or counts of arthropod taxa followed patterns similar to those of species rich- ness (Figs. 4b, 5). Ground arthropod counts averaged over the 7-year study period were greatest at the SEV sites, of which the black grama grassland habitat supported by far the greatest numbers of arthropods (Fig. 4b). BNM had the 2nd-greatest overall arthropod abundance, ranging from highest in the montane conifer forest, followed by the pinyon-juniper woodland and then the ponderosa pine forest. The Chihuahuan Desert habitats at JRN had the lowest overall ground arthropod counts, with greatest abundance within the black grama grassland.

\section{Spatial Patterns of Ground Arthropod Habitat Associations}

Cluster analysis of all 10 habitats from the 3 study sites based on ground arthropod species composition resulted in squared Euclidean distances $>0.50$ among all habitats and a distance of about 1.00 among the 3 sites (Fig. 6). The JRN creosotebush and tarbush habitats were most similar in ground arthropod species composition, followed by grassland and mesquite sand dune habitats. At BNM, montane conifer and ponderosa pine forests were more similar to each other than to the pinyon-juniper 

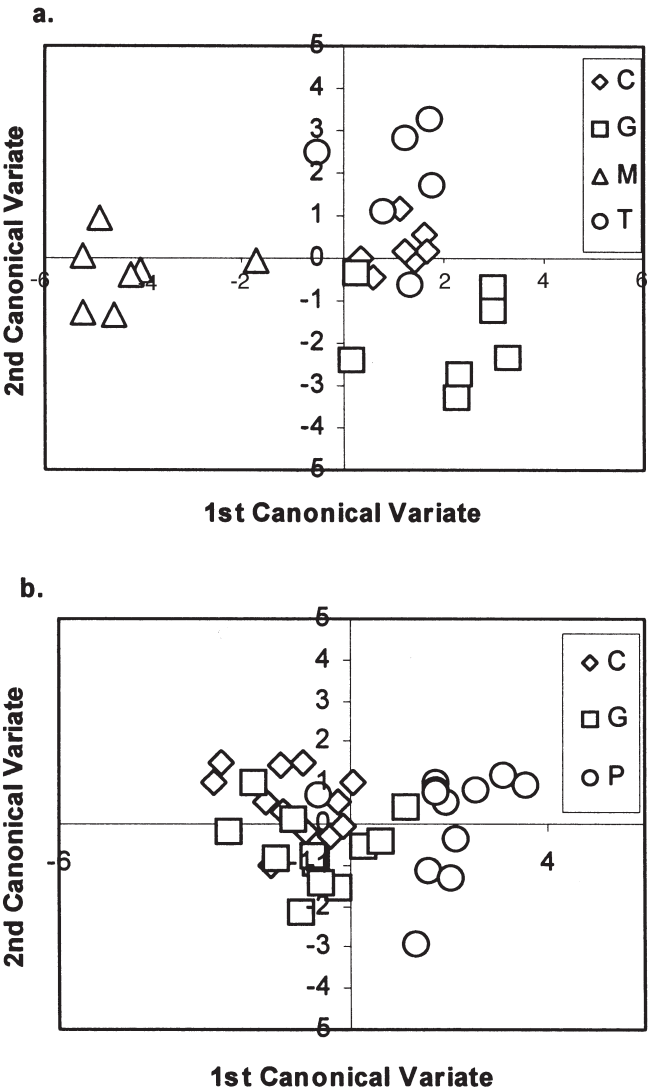

c.

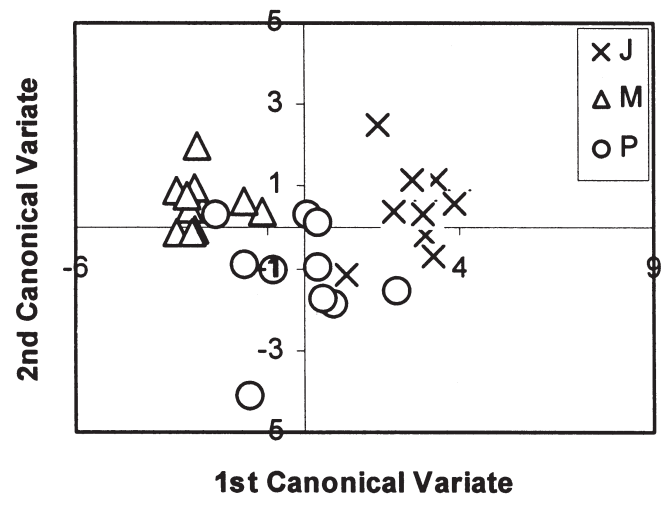

Fig. 7. Canonical discriminant function analysis ordination of Jornada (a), Sevilleta (b), and Bandelier (c) arthropod assemblages samples from the different habitats based on ground arthropod family-level composition and abundance averaged over a 6-year period. See text for explanation of canonical variates.

woodland, and at SEV, creosotebush and black grama grassland habitats were more similar to each other than to the pinyon-juniper woodland.
Arthropod species assemblages among different habitats within each of the 3 study sites were more similar to each other than to similar habitats across the 3 study sites: black grama grassland and creosotebush habitats at JRN were distinct from those at $\mathrm{SEV}$, and pinyonjuniper habitat at BNM was distinct from the pinyon-juniper habitat at SEV (Fig. 6).

Canonical discriminant function analysis (CDFA) tested for differences in ground arthropod taxonomic composition (at the family level) and in abundance among the habitats. The 4 JRN Chihuahuan Desert habitats were significantly different from each other $(P<0.0001$; Table 1, Fig. 7a). Standardized canonical coefficient scores revealed that spiders contributed most to the separation of JRN habitats, followed by millipedes, crickets, sun spiders, and bristletails. The Chihuahuan Desert, Rocky Mountain, and Western Short Grassland habitats at SEV were also significantly distinct $(P<0.01$; Table 1, Fig. 7b). Beetles contributed most to the separation of SEV habitats, followed by grasshoppers, spiders, centipedes, and millipedes. The Rocky Mountain forest woodland habitats at BNM supported significantly distinct assemblages $(P<0.0001)$, with spiders contributing most to the separation of habitats, followed by bristletails, sun spiders, and crickets (Table 1, Fig. 7c).

\section{Ecoregion Affinities of Selected Ground Arthropods}

Two arthropod orders, crickets/grasshoppers (Orthoptera) and spiders (Araneae), were well represented in the pitfall samples by 76 and 121 species, respectively, and were used to examine ecoregion affinities in detail based on published geographic distribution information (Appendix 2). Although many species occurred in $\geq 2$ ecoregions, the crickets/grasshoppers and spiders showed different patterns across the sites: orthopteran species richness was most similar between JRN and SEV, while spider species richness was most similar between SEV and BNM. Eight orthopteran species and 16 spider species were found at all 3 sites, representing $10 \%$ of the orthopterans and $16 \%$ of the spiders (Table 2).

Most of the cricket and grasshopper species (44 species) occurred in the Chihuahuan Desert, followed by lesser numbers of species associated with the Shortgrass Prairie, Southern Rocky Mountains, Colorado Plateau, and 
TABLE 1. Canonical discriminant function analysis for differences in ground arthropod taxonomic composition (family level) and abundance among the habitats within each of the 3 study sites. Habitats at Jornada were dominated by mesquite, tarbush, grass, and creosotebush; at Sevilleta by grass, creosotebush, and pinyon/juniper; and at Bandelier by pinyon/juniper, ponderosa pine, and mixed conifers.

\begin{tabular}{lccccccc}
\hline & & Jornada & & \multicolumn{2}{c}{ Sevilleta } & \multicolumn{2}{c}{ Bandelier } \\
\hline Overall multivariate $F$ test $($ prb. $>F)$ & & $<0.0001$ & & \multicolumn{2}{c}{$<0.01$} & \multicolumn{2}{c}{$<0.0001$} \\
Discriminant variates & 1 & 2 & 3 & 1 & 2 & 1 & 2 \\
Significance (prb. $>F)$ & $<0.0001$ & 0.01 & 0.08 & 0.01 & 0.74 & $<0.0001$ & 0.01 \\
Eigenvalue & 7.2 & 2.1 & 1.2 & 2.0 & 0.23 & 5.9 & 0.21 \\
Cumulative variance & $68 \%$ & $88 \%$ & $100 \%$ & $89 \%$ & $100 \%$ & $90 \%$ & $100 \%$ \\
\hline
\end{tabular}

TABLE 2. Total numbers of cricket/grasshopper and spider species found at each and different combinations of our 3 study sites.

\begin{tabular}{lcr}
\hline & $\begin{array}{c}\text { Crickets and } \\
\text { grasshoppers }\end{array}$ & Spiders \\
\hline Total species sampled & 76 & 121 \\
Jornada only & 6 & 10 \\
Sevilleta only & 13 & 35 \\
Bandelier only & 8 & 29 \\
Jornada and Sevilleta & 23 & 11 \\
Jornada and Bandelier & 0 & 0 \\
Sevilleta and Bandelier & 10 & 15 \\
Jornada, Sevilleta, and Bandelier & 10 & 21 \\
\hline
\end{tabular}

Arizona-New Mexico Mountains (Table 3). The Chihuahuan Desert also contributed the greatest number of species unique to an ecoregion (7 species), followed by the Southern Rocky Mountains (6 species). None of the species encountered in this study were unique to the Southern Shortgrass Prairie or to the Colorado Plateau, and only 2 species were unique to the Arizona-New Mexico Mountains.

Spider distributions showed a stronger response to an elevation-precipitation gradient from high richness at high elevation at BNM to lowest richness at JRN. Most spider species were associated with the Arizona-New Mexico Mountains and the Colorado Plateau. Species known from the Chihuahuan Desert and/or the Southern Rocky Mountains also made up a significant part of the fauna. The Shortgrass Prairie region contributed the fewest species. Eight species were reported from only a single ecoregion, and 6 of those were collected from the SEV transition site (Table 3).

\section{Discussion}

Local and Regional Community Similarity and Diversity

Results from cluster analysis (at the species level) and CDFA (at the family level) demon- strated that different habitats within a site (JRN, $\mathrm{SEV}$, or BNM) contained distinct ground arthropod assemblages (Figs. 6, 7). Although some species occurred in more than 1 habitat, abundances were not evenly distributed among them. In a similar study, Gering et al. (2003) showed that forest canopy beetles clearly formed different assemblages (with $<50 \%$ similarity) among the 3 sites in each of 2 ecoregions in forests of Ohio and Indiana. The pattern was maintained for early and late seasons, even with some changes in species composition.

Because of such differences within ecoregions, some researchers may not regard ecoregions as useful delineations for studies of biogeography. Wright et al. (1998) found a poor match between vegetation cover classes and ecoregion boundaries in the American Pacific Northwest. They expected vegetation cover to incorporate information about ecoreigon landforms and climate, but perhaps the varied topography of the region obscured the associations. McDonald et al. (2005) examined species turnover between pairs of adjacent ecoregions and found that similarity declined in the American Southwest, which also is topographically variable. We believe that some groups of plants and animals, and some heterogeneous regions, may not conform well to geographically defined ecoregions or portions of ecoregions. Biogeographic studies involving ecoregions also should address multiple taxa across classes and orders, and examine both species composition and richness.

The importance of regional species source areas to our study was especially clear when we examined arthropod species distributions across the 3 study sites. At this spatial scale, arthropod assemblages that shared common habitats as defined by dominant plant cover (pinyonjuniper habitat at SEV and BNM, desert grassland and creosotebush habitats at SEV and JRN) were not as similar to each other as they 
TABLE 3. Numbers of cricket/grasshopper species (in bold and below the diagonal) and spider species (above the diagonal) found in this study that are known to be associated with particular ecoregions (based on literature). The numbers in parentheses are species in this study reported to be unique to a particular ecoregion.

\begin{tabular}{lccccc}
\hline & $\begin{array}{c}\text { Chihuahuan } \\
\text { Desert }\end{array}$ & $\begin{array}{c}\text { Shortgrass } \\
\text { prairie }\end{array}$ & $\begin{array}{c}\text { Colorado } \\
\text { Plateau }\end{array}$ & $\begin{array}{c}\text { Arizona } \\
\text { mountains }\end{array}$ & $\begin{array}{c}\text { Southern } \\
\text { Rockies }\end{array}$ \\
\hline Chihuahuan Desert & $64(3)$ & 44 & 48 & 56 & 42 \\
Shortgrass prairie & $\mathbf{4 4}(\mathbf{7})$ & $46(1)$ & 37 & 40 & 34 \\
Colorado Plateau & $\mathbf{2 7}$ & $\mathbf{3 8 ( 0 )}$ & $77(1)$ & 67 & 71 \\
Arizona mountains & $\mathbf{2 3}$ & $\mathbf{2 4}$ & $\mathbf{3 4}(\mathbf{0})$ & $\mathbf{7 8 ( 2 )}$ & 57 \\
Southern Rockies & $\mathbf{2 1}$ & $\mathbf{2 1}$ & $\mathbf{2 0}$ & $\mathbf{2 9 ( 2 )}$ & $65(1)$ \\
& $\mathbf{1 7}$ & $\mathbf{2 2}$ & $\mathbf{2 3}$ & $\mathbf{2 2}$ & $\mathbf{3 6}(\mathbf{6})$ \\
\hline
\end{tabular}

were to other habitats within their ecoregions (Fig. 6). In Australia, MacNally et al. (2002) found that the match between ecoregion and faunal diversity depended on the animal taxa studied. Birds and mammals matched ecoregion boundaries more closely than invertebrates and reptiles. MacNally et al. (2002) identified arthropods only to order and acknowledged that greater taxonomic resolution might have improved the strength of regional associations. However, they confirmed that very different taxa do not substitute for each other and that no ecoregion definition will apply to all taxa.

\section{Species Distributions across the Transition Zone}

The SEV ecoregion transition site did contain greater species richness and abundance than comparable areas deeper within their respective ecoregions (BNM and JRN, Fig. 4) and the SEV arthropod assemblages were distinct from the other 2 sites (Fig. 6). Evidence for the ecotone or edge effect (Odum 1971) on other ground-dwelling arthropod communities has been mixed. In Israel, Krasnov and Shenbrot (1998) found that the distributions of ground-dwelling darkling beetle (tenebrionid) species did correspond to phytogeographic regions, with increased species diversity at phytogeographic boundaries. In contrast, Bestelmeyer and Wiens (2001) found that the geographic distributions of ground-dwelling ant species did not correspond to phytogeographically defined biomes of the shortgrass steppe (= Western Short Grassland; Ricketts et al. 1999) and Chihuahuan Desert region of North America, nor did ant species diversity increase at biome boundaries. For trees, birds, and mammals in North America, McDonald et al. (2005) found no marked increase in species turnover rates between pairs of adjacent ecoregions, based on range data and using ecoregion definitions of Ricketts et al. (1999). They did find increased turnover between ecotones that were also on biome boundaries or that followed major mountain ranges. In relation to our study, the SEV site was not only an area of ecoregional transition, it also was in the Southern Rio Grande Rift Valley, which is a transitional area for 3 continental biomes as described in the introduction section. One of our ecoregions, the Southern Rocky Mountains, does track part of a major mountain range, so some of the patterns we observed may be due to these larger geographical features and not just to ecoregions alone.

When we analyzed the ecoregion affinities of crickets and grasshoppers (Orthoptera) and spiders (Araneae) separately, we also found that not all ground arthropods reflected geographic affinities to the same degree. Orthopterans were clearly associated with particular ecoregions, and the overlap in taxa from different ecoregions, particularly Chihuahuan Desert and Western Short Grassland, did contribute to higher species diversity at SEV. Also, as herbivores, grasshoppers tend to specialize on particular plant taxa or groups (Otte and Joern 1977), which themselves tend to be part of the definition of an ecoregion.

Predatory spiders, in contrast, are less closely associated with plant species, although vegetation and substrate structure are important habitat features for them (Wise 1993). Our sites were dominated by the families Gnaphosidae and Lycosidae, both of which have numerous 
species associated with mesic microhabitats (e.g., Lowrie 1973 for Pardosa), as shown by the greatest contribution to our diversity coming from the higher-elevation ecoregions: Colorado Plateau, Arizona-New Mexico Mountains, and Southern Rocky Mountains. The high number of species from the Chihuahuan Desert came in part from families not represented from the higher elevations and from different species within widely distributed families. Our sites also shared 58\% of the spider species found in a study in shortgrass steppe in Colorado (Weeks and Holtzer 2000), in the Western Short Grasslands ecoregion, to the north of our sites. The distribution pattern for spiders in our study more closely matches a tracking of the precipitation gradient that Bestelmeyer and Wiens (2001) found in ants. Nevertheless, 6 of the 8 spider species that we sampled that were unique to an ecoregion (as reported in the literature) were from SEV, indicating that biogeographical transitional sites do contribute to regional biodiversity of spiders.

Results from our study did not fully support other likely alternative biogeographic hypotheses-namely, energy or productivity gradients-that would explain our patterns. The energy hypothesis (Hawkins et al. 2003) predicts increasing species diversity with increasing ambient temperature, precipitation, and evapotranspiration, and support for this hypothesis has been found in some arthropod groups (beetles-Kerr and Packer 1999; butterflies-Kerr 2001, Hawkins and Porter 2003). The productivity hypothesis (O'Brien 1998, Whittaker et al. 2003) predicts increasing species richness along with increasing ecosystem productivity, usually measured as plant net primary production (NPP). Temperature and precipitation in the desert Southwest tend to be negatively correlated across elevation gradients (Whittaker and Niering 1975, Brown 1982), often forcing a trade-off between preferred temperature and moisture conditions for arthropods (which are ectothermic animals). Waide et al. (1999) found no consistent relationship between productivity and species diversity for invertebrates within or between communities, or over spatial scales ranging from local $(<20 \mathrm{~km})$ to regional $(200-4000 \mathrm{~km})$.

Our findings that species composition and richness patterns were consistent with predictions based on ecoregions and edge effects and that these patterns were present among organisms as taxonomically diverse as arthropods in a region as physiographically diverse as the American Southwest indicate that recognition of large-scale biogeographic regions or provinces does have merit. Even though individual species distributions probably are relatively independent from each other, large geographic areas with similar climates and landscapes may support recognizable assemblages of ecologically similar ground arthropod species, as we found. Spatial patterns of terrestrial arthropod communities continue to be poorly understood compared to those of vascular plants and vertebrates. Our findings indicate that consideration of larger geographic source regions, such as ecoregions, may help elucidate patterns of arthropod community species composition and diversity at the local scale.

\section{ACKNOWLEDGMENTS}

We thank the many field technicians from Jornada LTER, Sevilleta LTER, and Bandelier National Monument who collected arthropod pit-trap samples for this study, especially Dara Parker, Mike Friggens, Karen Wetherill, Kay Beeley, and Rebecca Oertel. We thank George Ball, Jack Brookhart, Richard Fagerlund, Charles O’Brien, Greg Forbes, Paul Johnson, Robert Love, Luis Mendes, Gary Parsons, David Richman, Charles Triplehorn, and David Weissman for arthropod identifications. We thank Teri Neville of the Natural Heritage New Mexico Program for producing the study site map, Paul Neville of Earth Data Analysis Center (EDAC) for providing us with MODIS NPP values, and the data managers from the 3 sites for weather data. Ursula Shepherd and Mike Friggens provided thoughtful comments on earlier versions of the manuscript. This research was funded by National Science Foundation grants to the Jordana (DEB0080412) and Sevilleta (DEB-0080529) LTER programs, and research at Bandelier National Monument was funded by the National Park Service and U.S. Geological Survey (BRD Global Change Research Program, Western Mountain Initiative).

\section{Literature Cited}

ADIS, J. 1979. Problems of interpreting arthropod sampling with pitfall traps. Zoologische Anzeiger 202:177-184. Arnett, R.H., JR. 2000. American insects. CRC Press, Boca Raton, FL. 1003 pp. 
Axlerod, D.I. 1958. Evolution of the Madro-Tertiary geoflora. Botanical Review 24:433-509.

Bestelmeyer, B.T., and J.A. Wiens. 2001. Local and regional-scale responses of ant diversity to a semiarid biome transition. Ecography 24:381-392.

Brown, D.E., EDITOR. 1982. Biotic communities of the American Southwest: United States and Mexico. Desert Plants 4:1-342.

Brown, J.H. 1995. Macroecology, University of Chicago Press, Chicago, IL. 269 pp.

Brown, J.H., AND M.V. LomoLino. 1998. Biogeography. Sinauer and Associates, Sunderland, MA. 691 pp.

Crawford, C.S. 1981. Biology of desert invertebrates. Springer-Verlag, Berlin. $314 \mathrm{pp}$.

Dick-PedDie, W.A. 1993. New Mexico vegetation: past, present, and future. University of New Mexico Press, Albuquerque. $244 \mathrm{pp}$.

Digweed, S.C., C.R. Currie, H.A. Carcamo, and J.R SPENCE. 1995. Digging out the "digging-in effect" of pitfall traps: influences of depletion and disturbance on catch of ground beetles (Coleoptera: Carabidae). Pedobiologia 39:561-576.

Gering, J.C., T.O. Crist, and J.A. Veech. 2003. Additive partitioning of species diversity across multiple spatial scales: implication for regional conservation of biodiversity. Conservation Biology 17:488-499.

Hawkins, B.A., R. Field, H.V. Cornell, D.J. Currie, J.F Guegan, D.M. Kaufman, J.T. Kerr, et al. 2003. Energy, water, and broad-scale geographic patterns of species richness. Ecology 84:3105-3117.

Hawkins, B.A., AND E.E. Porter. 2003. Water-energy balance and the geographic pattern of species richness of western Palearctic butterflies. Ecological Entomology 28:678-686.

Hawley, J.W. 1978. Guidebook to the Rio Grande Rift in New Mexico and Colorado. New Mexico Bureau of Mines and Mineral Resources Circular 163:1-124.

Holland, M.M., P.G. Risser, and R.J. Naiman. 1991. Ecotones: the role of landscape boundaries in the management and restoration of changing environments. Chapman and Hall, NY. 142 pp.

HunT, C.B. 1983. Physiographic overview of our arid lands in the western U.S. Pages 7-63 in S.G. Wells and D.R. Haragan, editors, Origin and evolution of deserts. University of New Mexico Press, Albuquerque.

KERR, J.T. 2001. Butterfly species richness patterns in Canada: energy, heterogeneity, and the potential consequences of climatic change [online]. Conservation Ecology 5:10. Available from: http://www.consecol .org/vol5.iss/art10

Kerr, J.T., AND L. Packer. 1999. The environmental basis of North American species richness patterns among Epicauta (Coleoptera: Meloidae). Biodiversity and Conservation 8:617-628.

Krasnov, B.R., and G.I. Shenbrot. 1998. Structure of communities of ground-dwelling animals at the junction of two phytogeographic zones. Journal of Biogeography 25:1115-1131.

LOMOLINO, M.V., AND L.R. HEANEY, EDITORS. 2004. Frontiers of biogeography: new directions in the geography of nature. Sinauer and Associates, Sunderland, MA. 436 pp.

Lowrie, D.C. 1973. The microhabitats of western wolf spiders of the genus Pardosa. Entomological News 84:103-116.

MacNally, R., A.F. Bennett, G.W. Brown, L.F. Lumsden, A. Yen, S. Hinkley, P. Lillywhite, and D. Ward.
2002. How well do different ecosystem-based planning units represent different components of biodiversity? Ecological Applications 12:900-912.

McDonald, R., M. McKnight, D. Weiss, E. Selig, M. O'Connor, C. Violin, And A. Moody. 2005. Species compositional similarity and ecoregions: do ecoregion boundaries represent zones of high species turnover? Biological Conservation 126:24-40.

O'Brien, E.M. 1998. Water-energy dynamics, climate, and prediction of woody plant species richness: an interim general model. Journal of Biogeography 25:379-398.

Odum, E.P. 1971. Fundamentals of ecology. 3rd edition. W.B. Saunders Co., Philadelphia, PA. 574 pp.

Otte, D., AND A. Joern. 1977. On feeding patterns in desert grasshoppers and the evolution of specialized diets. Proceedings of the Academy of Natural Sciences of Philadelphia 128:89-126.

Parmenter, R.R., S.L. Brantley, J.H. Brown, C.S. Crawford, D.C. Lightfoot, and T.L. Yates. 1995. Diversity of animal communities on Southwestern rangelands: species patterns, habitat relationships, and land management. Pages 50-71 in N. West, editor, Biodiversity on rangelands: natural resources and environmental issues. Volume 4. College of Natural Resources, Utah State University, Logan.

Polis, G.A., EDITOR. 1991. The ecology of desert communities. University of Arizona Press, Tucson. $456 \mathrm{pp}$.

Poole, R.W., and P. Gentili, Editors. 2003. Nomina Insecta Nearctica. Entomological Information Services, Rockville, MD. 4 volumes, 3494 pp.

Ricketts, T.H., E. Dinerstein, D.M. Olson, C.J. Loucks, W. Eichbaum, D. DellaSala, K. Kavanagh, et al. 1999. Terrestrial ecoregions of North America: a conservation assessment. World Wildlife Fund, Island Press, Washington, DC. 485 pp.

Ricklefs, R.E., and G.L. Miller. 2000. Ecology. 4th edition. W.H. Freeman and Co., New York. 822 pp.

Ricklefs, R.E., AND D. SChluter, EDitors. 1993. Species diversity in ecological communities: historical and geographical perspectives. University of Chicago Press, Chicago, IL. 414 pp.

Risser, P.G. 1993. Ecotones at local to regional scales from around the world. Ecological Applications 3: 367-368.

. 1995. The status of the science examining ecotones. BioScience 45:318-325.

SAS InStituTe, InC. 2003. PC SAS, version 8.2. Statistical Analysis Systems, SAS Institute, Inc., Cary, NC.

SHMidA, A., AND M.W. Wilson. 1985. Biological determinants of species diversity. Journal of Biogeography $12: 1-20$.

SouthwOOD, T.R.E. 1966. Ecological methods: with particular reference to the study of insect populations. 2nd edition. Halsted Press, John Wiley \& Sons, Inc., New York. 391 pp.

Thomas, D.B., JR., And E.L. Sleeper. 1977. The use of pit-fall traps for estimating the abundance of arthropods, with special reference to the Tenebrionidae (Coleoptera). Annals of the Entomological Society of America 70:242-248.

UetZ, G.W., AND J.D. UnZicker. 1976. Pitfall trapping in ecological studies of wandering spiders. Journal of Arachnology 3:101-111.

Van Devender, T.R. 1995. Desert grassland history: changing climates, evolution, biogeography, and 
community dynamics. Pages 68-99 in M.P. McClaren and T.R. Van Devender, editors, The desert grassland. University of Arizona Press, Tucson.

Van Devender, T.R., And W.G. Spaulding. 1983. Development of vegetation and climate in the southwestern United States. Pages 131-156 in S.G. Wells and D.R. Haragan, editors, Origin and evolution of deserts. University of New Mexico Press, Albuquerque.

Waide, R.B., M.R. Willig, C.F. Steiner, G. MittelBaCH, L. Gough, S.I. Dodson, G.P. Juday, and R. PARMENTER. 1999. The relationship between productivity and species richness. Annual Review of Ecology and Systematics 30:257-300.

WARD, D.F., T.R. NEW, AND A.L. YEN. 2001. Effects of pitfall trap spacing on the abundance, richness and composition of invertebrate catches. Journal of Insect Conservation 5:47-53.

WeEks, R.D., JR., AND T.O. Holtzer. 2000. Habitat and season in structuring ground-dwelling spider (Araneae) communities in a shortgrass steppe ecosystem. Environmental Entomology 29:1164-1172.

WhitforD, W.G. 1986. Decomposition and nutrient cycling in deserts. Pages 93-117 in W.G. Whitford, editor, Pattern and process in desert ecosystems. University of New Mexico Press, Albuquerque.

WhitTaker, R.H. 1975. Communities and ecosystems. 2nd edition. Macmillan Publishing Company, New York. 385 pp.
WhitTaker, R.H., And W.A. Niering. 1975. Vegetation of the Santa Catalina Mountains, Arizona, USA. Part 5, Biomass production and diversity along the elevation gradient. Ecology 56:771-790.

Whittaker, R.J., K.J. Willis, and R. Field. 2003. Climatic-energetic explanations of diversity: a macroscopic perspective. Pages 107-129 in T.L. Blackburn and K.J. Gaston, editors, Macroecology: concepts and consequences. Blackwell Science, Oxford, U.K.

Wise, D.H. 1993. Spiders in ecological webs. Cambridge University Press, Cambridge, U.K. 328 pp.

Woodcock, B.A. 2005. Pitfall trapping in ecological studies. Pages 37-57 in S.R. Leather, editor, Insect sampling in forest ecosystems. Blackwell Publishing, Oxford, U.K.

Wright, R.G., M.P. Murray, and T. Merrill. 1998. Ecoregions as a level of ecological analysis. Biological Conservation 86:207-213.

Zhao, M., F.A. Heinsch, R.M. Ramakirshna, and S.W. RuNNING. 2005. Improvements of the MODIS terrestrial gross and net primary production global data set. Remote Sensing of Environment 95:164-176.

ZhaO, M., AND S.W. Running. 2006. Sensitivity of moderate resolution imaging spectroradiometer (MODIS) primary production to the accuracy of meterological reanalyses. Journal of Geophysical Research 111:1-13.

Received 22 January 2007 Accepted 10 October 2007 
APPENDIX 1. List of target arthropod species included in this study and their occurrence by site. $\mathrm{BNM}=$ Bandelier National Monument, SEV = Sevilleta Long-Term Ecological Research areas, JRN = Jornada Basin LongTerm Ecological Research areas.

\begin{tabular}{|c|c|c|c|c|c|c|c|}
\hline \multirow{2}{*}{\multicolumn{4}{|c|}{ in this study and their occurrence by site. $\mathrm{BNM}=$ Bande- }} & & & & \\
\hline & & & & Taxon & $\mathrm{BNM}$ & SEV & JRN \\
\hline Ecological Research areas, JRN & orna & $B$ & & Dictyna sp. 1 & & & 5 \\
\hline Term Ecological Research areas. & & & & Dictyna sp. 2 & & 11 & \\
\hline Taxon & $\mathrm{BNM}$ & SEV & $\overline{\mathrm{JRN}}$ & $\begin{array}{l}\text { dictynid immatures } \\
\text { Family Filictatidae }\end{array}$ & & 4 & \\
\hline Class Chilopoda - centipedes & & & & Filistatinella sp. & & 14 & \\
\hline Order Geophilomorpha & & & & Kukulcania hibernalis & & 3 & \\
\hline Family Diagnothodontidae & & & & Family Gnaphosidae & & & \\
\hline Strigamia chionophila & 16 & & & Callilepis chisos & & 3 & \\
\hline Order Lithobiomorpha & & & & C. mumai & 6 & 16 & 2 \\
\hline Family Lithobiidae & & & & Cesonia sincera & & 36 & 6 \\
\hline Anobius centurio & 1 & & & Drassodes gosiutus & 2 & 30 & 20 \\
\hline Lithobius forficatus & & & 4 & Dd. neglectus & 6 & 1 & \\
\hline Nadabius holzingeri & 9 & & & Dd. saccatus & 2 & 53 & \\
\hline Nadabius mesenchinus & 47 & & & Drassyllus antonito & & 1 & \\
\hline Nadabius pullus & 12 & & & Dr. conformans & & 8 & \\
\hline Paitobius juventus & 2 & & & Dr. dromeus & 8 & 34 & \\
\hline Pokabius bilabiatus & 3 & & & Dr. insularis group & & 1 & \\
\hline Taiubius harrietae & 2 & 2 & & Dr. lamprus & & 3 & \\
\hline Order Scolopendromorpha & & & & Dr. lepidus & & 1 & 1 \\
\hline Family Scolopendridae & & & & Dr. mexicanus & & 6 & \\
\hline Scolopendra polymorpha & 1 & 53 & 3 & Dr. mormonus & & 7 & \\
\hline Class Diplopoda - millipedes & & & & Dr. mumai & & 42 & 1 \\
\hline Order Parajulida & & & & Dr. orgilis & 1 & 2 & \\
\hline Family Parajulidae & & & & Gnaphosa clara & 1 & 2 & 3 \\
\hline Oriulus medianus & 259 & & & G. muscorum & 92 & & \\
\hline parajulid sp. & & 14 & & Halpodrassus bicornis & 2 & & \\
\hline Order Polydesmida & & & & Ha. chamberlini & 14 & 133 & 21 \\
\hline Family Polydesmidae & & & & Ha. dixianus & 8 & & \\
\hline Utadesmus hoffi & 2 & & & Ha. eunis & 3 & & \\
\hline Order Spirostreptida & & & & Ha. signifer & 17 & & \\
\hline Family Spirostreptidae & & & & Herpyllus bubulcus & 1 & 25 & 23 \\
\hline Orthoporus ornatus & & 7 & 8 & He. cockerelli & 5 & & \\
\hline Class Arachnida & & & & He. excelsus & & 1 & \\
\hline Order Araneae - spiders & & & & He. hesperolus & 1 & 34 & \\
\hline Family Agelenidae & & & & He. propinquus & & 2 & \\
\hline Agelenopsis sp. & & & 1 & Micaria aenea & 3 & 2 & \\
\hline A. longistylus & & 12 & & M. gosiuta & & 4 & \\
\hline Agelenopsis utahensis & 2 & 2 & & M. imperiosa & & 10 & \\
\hline Hololena hola & 39 & 17 & & M. longipes & & & 17 \\
\hline Novalena lutzi & 5 & & & M. porta & & 1 & 4 \\
\hline agelenid immatures & 6 & 33 & & M. pulicaria & 4 & & \\
\hline Family Anyphaenidae & & & & M. nr. triangulosa & & & 1 \\
\hline Anyphaena dixiana & & 16 & & Nodocion utus & & 1 & \\
\hline A. hespar & 13 & & & Orodrassus coloradensis & 8 & & \\
\hline A. marginalis & 2 & & & Zelotes anglo & 2 & 24 & 6 \\
\hline A. pacifica & 2 & & & Z. fratris & 23 & & \\
\hline Hibana incursa & & 3 & & Z. lasalanus & 7 & 22 & 1 \\
\hline anyphaenid immatures & 26 & 38 & & Z. puritanus & 12 & & \\
\hline Family Clubionidae & & & & Z. tuobus & 21 & 80 & 11 \\
\hline Clubiona sp. & & 53 & & gnaphosid immatures & 90 & 1599 & 7 \\
\hline clubionid immatures & & 25 & & Family Linyphiidae & & & \\
\hline Family Corinnidae & & & & combined species & 88 & 107 & 2 \\
\hline Castianeira sp. 1 & 3 & & & Pityohyphantes sp. & 14 & & \\
\hline Castianeira sp. 2 & & & 19 & Family Lycosidae & & & \\
\hline Castianeria sp. 3 & & 3 & & Alopecosa kochi & 130 & 112 & \\
\hline C. occidentalis & & 71 & & Geolycosa rafaelana & & 4 & 1 \\
\hline Meriola decepta & & 2 & & Hogna carolinensis & 1 & 35 & 2 \\
\hline corinnid immatures & & 3 & & H. frondicola & 6 & 2 & \\
\hline Family Dictynidae & & & & Pardosa montanensis & 23 & & \\
\hline Cicurina deserticola & 1 & & & P. orophila & 5 & 177 & \\
\hline C. robustus & 31 & & & P. uncata & 503 & & \\
\hline Cicurina spp. & 72 & 98 & 9 & P. xerophila & 12 & & \\
\hline C. varians & 11 & & 3 & P. yavapa & 101 & & \\
\hline
\end{tabular}

ApPEndix 1. Continued. 
APPENDIX 1. Continued.

\begin{tabular}{|c|c|c|c|c|c|c|c|}
\hline Taxon & $\mathrm{BNM}$ & SEV & $\mathrm{JRN}$ & Taxon & $\mathrm{BNM}$ & SEV J & $\mathrm{JRN}$ \\
\hline Schizocosa chiricahua & & 12 & & Eurybunus brunneus & 6 & & \\
\hline S. mccooki & 60 & 39 & 8 & sclerosomatid sp. & & 15 & \\
\hline S. mimula & 2 & 1 & & Togwoteeus biceps & 271 & & \\
\hline Trochosa terricola & 11 & 2 & & Trachyrhinus marmoratus & 624 & & \\
\hline Varacosa gosiuta & 34 & 17 & 2 & Family Triaenonychidae & & & \\
\hline lycosid immatures & 193 & & 2 & Sclerobunus robustus & 14 & & \\
\hline Family Liocranidae & & & & Order Scorpiones - scorpions & & & \\
\hline Neoanagraphis chamberlini & & 3 & 1 & Family Vaejovidae & & & \\
\hline Family Mimetidae & & & & Vaejovis coahuilae & & 523 & 138 \\
\hline Mimetus hesperus & & 8 & 2 & V. russelli & & 2 & 1 \\
\hline Family Miturgidae & & & & Order Uropygi - vinegaroons & & & \\
\hline Cheiracanthium inclusum & & & 2 & Family Thelyphonidae & & & \\
\hline Syspira sp. & & & 17 & Mastigoproctus giganteus & & 14 & \\
\hline Family Oxyopidae & & & & Class Insecta & & & \\
\hline Oxyopes lynx & & 6 & & Order Archaeognatha - bristletails & & & \\
\hline O. salticus & & 2 & & Family Meinertellidae & & & \\
\hline O. tridens & & & 27 & Machilinus aurantiacus & 788 & 1199 & \\
\hline Family Philodromidae & & & & Praemachilellus rentzi & & & 545 \\
\hline Apollophanes texanus & & 10 & 31 & Family Machilidae & & & \\
\hline Ebo sp. & 3 & & & Mesomachilis sp. & & 3 & \\
\hline Ebo parabolis & & 22 & 24 & Order Dictyoptera - cockroaches, 1 & mantises & & \\
\hline Philodromus infuscatus & 1 & & & Family Blattellidae & & & \\
\hline P. keyserlingi & & 3 & & Parcoblatta desertae & & & 21 \\
\hline Thanatus coloradensis & 1 & 51 & 10 & Family Polyphagidae & & & \\
\hline Tibellus duttoni & & 8 & & Arenivaga erratica & & 54 & 65 \\
\hline Family Salticidae & & & & Eremoblatta subdiaphana & & 6 & 13 \\
\hline Habronattus clypeatus & & 55 & & Family Mantidae & & & \\
\hline H. conjunctus & 1 & 1 & & Litaneutria minor & & 6 & 2 \\
\hline H. geronimoi & & 9 & 14 & Yersiniops solitaria & & 3 & \\
\hline Metacyrba taeniola & & & 2 & Order Orthoptera - grasshoppers, 1 & katydids, & , crickets & \\
\hline Pellenes limatus & & 1 & & Family Acrididae & & & \\
\hline Phidippus spp. & 5 & 6 & 5 & Acantherus piperatus & & 35 & 58 \\
\hline Platycryptus arizonenesis & & 14 & & Aeoloplides elegans & & & \\
\hline Sassacus sp. & & & 12 & Ageneotettix deorum & & 48 & \\
\hline salticid immatures & 8 & 110 & & Amphitornus coloradus & & 16 & 2 \\
\hline Family Sicariidae & & & & Arphia conspersa & 22 & 410 & 2 \\
\hline Loxosceles apachea & & 4 & 2 & A. pseudonietana & 5 & 54 & 6 \\
\hline Family Theridiidae & & & & Aulocara femoratum & & 444 & \\
\hline Euryopes scriptipes & 17 & 8 & 6 & Barytettix humphreysi & & 9 & \\
\hline Latrodectus hesperus & 22 & 35 & 8 & Bootettix argentatus & & 280 & 23 \\
\hline Steatoda sp. & & 1 & & Camnula pellucida & 1 & & \\
\hline S. fulva & 2 & 7 & 11 & Campylacantha olivacea & & & 13 \\
\hline S. hespera & 5 & & & Chorthippus curtipennis & 16 & & \\
\hline theridiid immatures & 7 & & 1 & Cibolacris parviceps & & 98 & 42 \\
\hline Family Thomisidae & & & & Clematodes larreae & & & 7 \\
\hline Bassaniana versicolor & & 2 & & Cordillacris crenulata & & 1 & \\
\hline Misumenops sp. & & 1 & & C. occipitalis & & 23 & 2 \\
\hline Xysticus apachecus & & 9 & & Dactylotum bicolor & & 29 & 1 \\
\hline X. cunctator & 6 & 6 & 1 & Eritettix simplex & 6 & 57 & 13 \\
\hline X. facetus & 1 & 24 & 3 & Heliaula rufa & & 19 & \\
\hline X. gosiutus & 1 & & & Hesperotettix viridis & 1 & 2 & 2 \\
\hline X. gulosus & 2 & 10 & & Hippopedon capito & & 3 & 1 \\
\hline X. lassanus & 1 & 77 & 9 & L. wheeleri & & 6 & \\
\hline X. locuples & 6 & 11 & & Ligurotettix planum & & & 9 \\
\hline X. luctuosus & 9 & & & Melanoplus aridus & 6 & 2 & \\
\hline X. montanensis & 19 & & & M. arizonae & & 53 & \\
\hline X. orizaba & & 7 & & M. bowditchi & & 56 & 3 \\
\hline thomisid immatures & 13 & 168 & 22 & M. femur-nigrum & 3 & & \\
\hline Order Solifugae - solifugids, sun s & piders & & & M. gladstoni & 3 & 26 & \\
\hline Family Eremobatidae & & & & M. lakinus & & 10 & 2 \\
\hline Eremobates sp. & 232 & 253 & 129 & M. occidentalis & 3 & & \\
\hline Order Opiliones - harvestmen & & & & M. packardi & & 1 & \\
\hline Family Sclerosomatidae & & & & M. splendidus & 3 & 3 & \\
\hline
\end{tabular}


APPEndix 1. Continued.

\begin{tabular}{|c|c|c|c|c|c|c|c|}
\hline Taxon & $\mathrm{BNM}$ & SEV & JRN & Taxon & $\mathrm{BNM}$ & SEV & JRN \\
\hline Mestobregma plattei & & 21 & & Lygaeus kalmi & & 43 & 5 \\
\hline Opeia obscura & & 18 & 3 & Melacoryphus lateralis & & & 2 \\
\hline Paropomala pallida & & 15 & 4 & Ozophora sp. & & 172 & \\
\hline Phlebostroma quadrimaculatun & & 3 & & Prytanes sp. & & 2 & \\
\hline Phoetaliotes nebracensis & & 2 & & Sphragisticus sp. & & 1 & \\
\hline Psoloessa delicatula & & 227 & 3 & Family Miridae & & & \\
\hline P. texana & 37 & 700 & 8 & Eustictus sp. & & 560 & \\
\hline Spharagemon equale & & 2 & & Order Coleoptera - beetles & & & \\
\hline Syrbula admirabilis & & 7 & & Family Anobiidae & & & \\
\hline S. montezuma & & 53 & & anobiid sp. & & & 23 \\
\hline Trachyrhachys kiowa & & 9 & 1 & Niptus ventriculus & & & 1 \\
\hline Trimerotropis californica & & 8 & 4 & Family Carabidae & & & \\
\hline T. cincta & 6 & 2 & & Amara sp. & 1 & & \\
\hline T. modesta & 3 & & & A. apachensis & & 5 & \\
\hline T. pallidipennis & 67 & 940 & 86 & A. discors & & 8 & \\
\hline T. pistrinaria & & 12 & & A. erratica & & 4 & \\
\hline T. suffusa & 16 & & & A. nr. idahoana & & 20 & \\
\hline Tropidolophus formosus & & 9 & 5 & A. rubrica & & 30 & \\
\hline Xanthippus corallipes & 4 & 54 & 6 & Calosoma obsoletus & & 2 & \\
\hline acridid immatures & 55 & 642 & 19 & C. peregrinator & & 12 & \\
\hline Family Gryllidae & & & & Carabus taedatus & 787 & & \\
\hline Gryllus sp. 1 undescribed & & 428 & 613 & Cicindela lemniscata & & 4 & 2 \\
\hline Gryllus pennsylvanicus & & 314 & & C. pulchra & & 13 & \\
\hline G. personatus & & 439 & & C. punctulata & & 28 & \\
\hline Gryllus sp. 2 undescribed & 113 & & & Cymindis arizonensis & 1 & 49 & \\
\hline Oecanthus californicus & 14 & 12 & & C. cribricollis & 2 & & \\
\hline gryllid immatures & & 733 & 5 & C. punctigera & 9 & 110 & 11 \\
\hline Family Mogoplistidae & & & & Dyschirius sp. & 2 & & \\
\hline Cycloptilium comprehendens & 26 & 2634 & 37 & D. globulosa & & 5 & \\
\hline Hoplosphyrum boreale & & 363 & & Euryderus grossus & & 10 & 2 \\
\hline Family Rhaphidophoridae & & & & Harpalus amputatus & & 12 & \\
\hline Ammobaenetes phrixocnemoide & & & 30 & H. katiae & & 1 & \\
\hline Ceuthophilus lamellipes & & 5 & & H. pennsylvanicus & & 1 & 2 \\
\hline C. pallidus & 195 & 155 & & H. tadorcus & & 149 & \\
\hline C. utahensis & 4111 & 38 & & Helluomorphoides ferruginea & & 1 & \\
\hline C. variegatus & & & 53 & He. latitarsus & & 1 & 4 \\
\hline Daihiniodes hastiferum & & 919 & 7 & Lebia viridis & 2 & 21 & \\
\hline Styracosceles neomexicana & 3 & & & Notiophilus novemstriatus & 19 & & \\
\hline rhaphidophorid immatures & & 922 & & Pasimachus californicus & & 56 & 53 \\
\hline Family Stenopelmatidae & & & & P. elongatus/obsoletus & & 1693 & 15 \\
\hline Stenopelmatus fuscus & 153 & 130 & & Poecilus lucublandus & & 1 & \\
\hline Stenopelmatus sp. 1 undescrib & bed & 9 & & Pterostichus adstrictus & 1019 & & \\
\hline Family Tettigoniidae & & & & Rhadine dissectus & & 2 & \\
\hline Arethaea gracilipes & 2 & 33 & 9 & Rhadine sp. 3 & & 1 & \\
\hline Capnobotes fuliginosus & & 1 & 1 & R. umbra group & 24 & & \\
\hline Dichopetala brevihastata & & & 5 & Scaphinotus snowi & 2 & & \\
\hline Eremopedes balli & 1 & 27 & & Scarites subterraneus & & 5 & \\
\hline E. bilineata & & 14 & & Tachys sp. & 1 & & \\
\hline E. scudderi & & 237 & 34 & Family Cryptophagidae & & & \\
\hline Insara elegans & & 9 & 37 & cryptophagid sp. 1 & 14 & 116 & \\
\hline Insara juniperi & 3 & 7 & & Cryptophagus dentatus & 19 & & 11 \\
\hline tettigoniid immatures & & 41 & 1 & C. fumidulus & & 1 & \\
\hline Order Hemiptera - true bugs & & & & C. stromus & & 9 & \\
\hline Family Aradidae & & & & Myrmedophila americanus & 1 & & \\
\hline Aradus lugubris & 9 & & & Family Curculionidae & & & \\
\hline Family Cydnidae & & & & Apion sp. & & 1 & \\
\hline cydnid sp. & & 1884 & & Cimbocera buchanani & & 31 & \\
\hline Dallasiellus discrepans & 6 & 1197 & 6 & C. conspersa & & 2 & 10 \\
\hline Family Lygaeidae & & & & Cleonidius poricollis & & 1 & \\
\hline Emblethis vicarius & 33 & 310 & 40 & Crocidema sp. & & 4 & \\
\hline Geocoris sp. & & 5 & & curculionid sp. & 1 & & \\
\hline lygaeid sp. 2 & 1 & & & Gerstaeckeria lecontei & & 17 & \\
\hline lygaeid sp. 28 & & 2 & & G. turbida & & 1 & \\
\hline
\end{tabular}


APPEndix 1. Continued.

\begin{tabular}{|c|c|c|c|c|c|c|c|}
\hline Taxon & BNM & SEV & JRN & Taxon & $\mathrm{BNM}$ & SEV & JRN \\
\hline Hypera postica & & 1 & & Anatropis verticalis & & & 152 \\
\hline Minyomerus languidus & & 8 & 3 & Aphodius sp. 1 & & 4 & \\
\hline Notiodes limatulus & & 8 & & Aphodius sp. 2 & & & 1 \\
\hline Ophryastes sp. & & & 7 & Aphodius sp. 3 & & 1 & \\
\hline O. dunnianus & & 1 & & Boreocanthon ebenus & & & 2 \\
\hline O. globularis & & 45 & & B. probus & & 1 & \\
\hline O. latirostris & & 1 & & Canthon puncticollis & & & 5 \\
\hline O. sulcatus & & 3 & 3 & Cremastocheilus planatus & & 2 & \\
\hline O. vittatus & & 1 & 2 & Diplotaxis sp. 1 & 17 & & \\
\hline Pandeleteius dentipes & & 3 & & Diplotaxis sp. 2 & & 32 & \\
\hline Rhypodillus brevicollis & & 1 & & Diplotaxis sp. 3 & & 114 & \\
\hline Sapotes longipilis & & 37 & & D. carbonata & 1 & & 18 \\
\hline S. puncticollis & & 5 & & D. knausi & & & 19 \\
\hline Scyphophorus acupunctatus & & 2 & & D. subangulata & 6 & 25 & 9 \\
\hline Sitona hispidulus & & 1 & & Euphoria inda & 127 & 37 & 3 \\
\hline Smicronyx sp. & & & 1 & Hoplia laticollis & & 1 & \\
\hline Sphenophorus sp. & 1 & & & Onthophagus sp. & & 1 & \\
\hline Yuccaborus frontalis & & 5 & & O. hecate & & & 5 \\
\hline Family Elateridae & & & & Paracotalpa puncticollis & & 13 & \\
\hline Aeolus mellillus & & 2 & & Phyllophaga sp. & 5 & & \\
\hline Agrypnus rectangularis & 50 & & 6 & P. vetula & 3 & 14 & \\
\hline Cardiophorus sp. & & 89 & & P. wickhami & & 160 & \\
\hline Conoderus athoides & & 27 & 5 & scarabaeid sp. 46 & & 16 & \\
\hline Ctenicara carbo & & 4 & & scarabaeid sp. 51 & & 1 & \\
\hline C. pudica & 3 & & & scarabaeid sp. 57 & & 4 & \\
\hline Glyphonyx sp. & 1 & & & scarabaeid sp. 60 & & 1 & \\
\hline Heteroderes sordidus & & 2 & & Family Staphylinidae & & & \\
\hline Horistonotus simplex & & 19 & & aleocharine spp. & 1265 & 6 & \\
\hline Lanelater schotti & 9 & 1816 & 121 & Carphacis nepigonensis & 4 & & \\
\hline Limonius lanei & 7 & & & Dexiogyia sp. & 11 & & \\
\hline Melanotus similis & & 1 & & Hapalaraea cacti & & & 2 \\
\hline Neotrichophorus arizonensis & & 2 & 7 & Lordithon arizonensis & 46 & & \\
\hline Family Endomychidae & & & & omaliine sp. 1 & 1 & 11 & \\
\hline Aphorista sp. & 1 & & & Ocypus ater & & 3 & \\
\hline Family Erotylidae & & & & Oxytelus sp. & 2 & & \\
\hline Cypherotylus californicus & 3 & & & Parothius sp. & 2 & & \\
\hline Family Histeridae & & & & Philolonthus sp. & 1 & & \\
\hline Hister abbreviatus & 9 & & 32 & Pseudopsis callosa & 3 & & \\
\hline Iliotona cacti & & 5 & 1 & Quedius desertus & 1 & 4 & \\
\hline Saprinus sp. & 1 & & & staphylinine sp. 1 & 1 & & \\
\hline S. discoidalis & & 34 & & staphylinine sp. 2 & 1 & & \\
\hline S. pennsylvanicus & & 5 & & Tachyporus jocusus & 55 & & \\
\hline Xerosaprinus sp. 1 & & & 1 & Family Tenebrionidae & & & \\
\hline Xerosaprinus sp. 2 & & 399 & & Anepsius sp. & & 221 & \\
\hline Family Lathridiidae & & & & Araeoschizus decipiens & & 194 & 39 \\
\hline Corticaria rudis & 8 & & & Argoporis rufipes & & 50 & 6 \\
\hline Family Leiodidae & & & & Blapstinus fortis & 1 & 1 & \\
\hline Catops basilarus & 1 & & & B. pimalis & & 61 & 4 \\
\hline Ptomaphagus texanus & 14 & 1 & 16 & Conibius uniformis & & & 15 \\
\hline Family Nitidulidae & & & & Edrotes leechi & & 5 & \\
\hline Carpophilus sp. & 2 & & & Ed. rotundus & & 23 & \\
\hline C. humeralis & 67 & & & Eleodes carbonarius & & 6 & \\
\hline C. lugubris & 45 & 2 & 69 & E. caudiferus & & 48 & 4 \\
\hline C. pallidipennis & 26 & & & E. debilis & 1 & & \\
\hline C. sayi & & & 3 & E. extricatus & 594 & 1193 & 8 \\
\hline Epuraea adumbrata & 4 & & & E. fusiformis & & 9 & \\
\hline Phenolia grossa & 15 & & & E. gracilis & & 369 & 4 \\
\hline Thalycra keltoni & 7 & & & E. hispilabris & & 15 & 125 \\
\hline Family Ptiliidae & & & & E. hoppingi & 80 & & \\
\hline Acrotrichus sp. & 83 & & & E. longicollis & 8 & 1410 & 39 \\
\hline Family Salpingidae & & & & E. nigrinus & 99 & & \\
\hline Elacatis umbrosus & 2 & & & E. obscurus & 339 & & \\
\hline Family Scarabaeidae & & & & E. obsoletus & & 92 & 5 \\
\hline
\end{tabular}


Appendix 1. Continued.

\begin{tabular}{lrrr}
\hline Taxon & BNM & SEV & JRN \\
\hline \multirow{2}{*}{ E. pimelioides } & 8 & & \\
E. sponsus & & 33 & \\
E. tenuipes & & 94 & \\
E. tricostatus & 17 & \\
Embaphion contusum & 31 & 1 & 1 \\
Em. glabrum & & & 3 \\
Em. planum & 10 & \\
Eupsophulus castaneus & & & 3 \\
Eusattus reticulatus & & 3 & 3 \\
Glyptasida sordida & & 16 & 2 \\
Gonasida elata & & 6 & \\
Helops callosa & & 8 & \\
Lobometopon fusiformis & & 12 & \\
Megasida obliterata & & 32 & \\
M. tenuicollis & & 173 & 32 \\
Melanastus sp. 1 & 345 &
\end{tabular}

Appendix 1. Continued.

\begin{tabular}{lrrr}
\hline Taxon & BNM & SEV & JRN \\
\hline & & 3 & \\
Me. coarcticollis & & 9 & \\
Metopoloba pruinosus & 12 & & \\
Metaponium sp. 1 & 1 & & \\
Mt. cribriceps & & 24 & \\
Mt. implicans & 5 & \\
Neobaphion planipennis & & 16 & 9 \\
Stenomorpha consors & & 29 & \\
S. convexicollis & & 1 & \\
S. obovata & & 7 & \\
S. rimata & 30 & 540 & \\
S. severa & & 1 & \\
Steriphanus convexus & & 28 & 22 \\
Telabis histricus & & 3 & \\
Trimytis pruinosa & & & \\
Trogloderis costatus & & &
\end{tabular}


APPEnDix 2. References for the geographic distributions of spider, cricket, and grasshopper species relative to the Southern Rio Grande Rift.

BRADY, A.R. 1964. The lynx spiders of North America, north of Mexico (Araneae: Oxyopidae). Bulletin of the Museum of Comparative Zoology 131:429-518.

1979. Nearctic species of the wolf spider genus Trochosa (Araneae: Lycosidae). Psyche 86:167-212.

Chamberlin, R.V. 1923. The North American species of Mimetus. Journal of Entomology and Zoology (Claremont) 15:3-9.

1924. The spider fauna of the shores and islands of the Gulf of California. Proceedings of the California Academy of Sciences 12:561-694.

ChamberLin, R.V., and W. IVIE. 1940. Agelenid spiders of the genus Cicurina. Bulletin of the University of Utah 30:1-107.

. 1941. North American Agelenidae of the genera Agelenopsis, Calilena, Ritalena and Tortolena. Annals of the Entomological Society of America 34:585-628.

1942. Agelenidae of the genera Hololena, Novalena, Rualina and Melpomene. Annals of the Entomological Society of America 35:203-241.

Dondale, C.D., AND J.H. Redner. 1969. The infuscatus and dispar groups of the spider genus Philodromus in North and Central America and the West Indies (Araneida: Thomisidae) Canadian Entomologist 101:921-954.

1975. Revision of the spider genus Apollophanes (Araneida: Thomisidae). Canadian Entomologist 107: 1175-1192.

1976. A review of the spider genus Philodromus in the Americas (Araneida: Philodromidae). Canadian Entomologist 108:127-157.

1978. Revision of the nearctic wolf spider genus Schizocosa (Araneae: Lycosidae). Canadian Entomologist 110:143-181.

. 1979. Revision of the wolf spider genus Alopecosa Simon in North America (Araneae: Lycosidae). Canadian Entomologist 111:1033-1055.

1990. The wolf spiders, nurseryweb spiders and lynx spiders of Canada and Alaska: Araneae: Lycosidae, Pisauridae, and Oxyopidae. Insects and Arachnids of Canada 17:1-383.

Dondale, C.D., A.L. Turnbull, and J.H. Redner. 1964. Revision of the Nearctic species of Thanatus C.L. Koch (Araneae: Thomisidae). Canadian Entomologist 96:636-656.

EDWARDS, R.J. 1958. The spider subfamily Clubioninae of the United States, Canada and Alaska (Araneae: Clubionidae). Bulletin of the Museum of Comparative Zoology 118:365-436.

Gertsch, W.J. 1933. Notes on American spiders of the family Thomisidae. American Museum Novitates 593:1-22.

1935. Spiders from the southwestern United States, with descriptions of new species. American Museum Novitates 792:1-31.

1939. A revision of the typical crab-spiders (Misumeninae) of America north of Mexico. Bulletin of the American Museum of Natural History 76:277-442.

1953. The spider genera Xysticus, Coriarachne, and Oxyptila (Thomisidae, Misumeninae) in North
APPEndix 2. Continued.

America. Bulletin of the American Museum of Natural History 102:417-482.

GerTsch, W.J., And F. EnNik. 1983. The spider genus Loxosceles in North America, Central America, and the West Indies. Bulletin of the American Museum of Natural History 175:264-360.

HeLFER, J.R. 1987. How to know the grasshoppers, crickets, cockroaches, and their allies. Dover Publications, Inc., New York. 363 pp.

HubbeLL, T.H. 1936. A monographic revision of the genus Ceuthophilus (Orthoptera, Gryllacrididae, Raphidophorinae). University of Florida Biological Series, $2,1-551$.

Kaston, B.J. 1970. Comparative biology of American black widow spiders. Transactions of the San Diego Society of Natural History 16:33-82.

LEVI, H.W. 1954. Spiders of the genus Euryopis from North and Central America (Araneae,Theridiidae). American Museum Novitates 1666:1-48.

1957. The spider genera Crustulina and Steatoda in North America, Central America, and the West Indies (Araneae,Theridiidae). Bulletin of the Museum of Comparative Zoology 117:367-424.

Lowrie, D.C., AND C.D. Dondale. 1981. A revision of the nigra group of the genus Pardosa in North America. Bulletin of the American Museum of Natural History 170:125-139.

Oтte, D. 1981. The North American grasshoppers. Volume 1. Acrididae, Gomphocerinae and Acridinae. Harvard University Press, Cambridge, MA. 275 pp. . 1984. The North American grasshoppers. Volume 2. Acrididae, Oedopodinae. Harvard University Press, Cambridge, MA. 376 pp.

Platnick, N.I. 1974. The spider family Anyphaenidae in America north of Mexico. Bulletin of the Museum of Comparative Zoology 146:205-266.

1975. A revision of the holarctic spider genus Callilepis (Araneae, Gnaphosidae). American Museum Novitates 2573: 1-32.

Platnick, N.I., AND A. LaU. 1975. A revision of the celer group of the spider genus Anyphaena (Araneae, Anyphaenidae) in Mexico and Central America. American Museum Novitates 2575:1-36.

Platnick, N.I., AND M.U. Shadab. 1974. A revision of the bispinosus and bicolor groups of the spider genus Trachelas (Araneae, Clubionidae) in North and Central America and the West Indies. American Museum Novitates 2560:1-34.

1975a. A revision of the spider genus Gnaphosa (Araneae, Gnaphosidae) in America. Bulletin of the American Museum of Natural History 155:1-65.

1975b. A revision of the spider genera Haplodrasus and Orodrassus (Araneae, Gnaphosidae). American Museum Novitates 2583:1-40.

1976. A revision of the spider genera Drassodes and Tivodrassus (Araneae, Gnaphosidae) in North America. American Museum Novitates 2593:1-29.

1977. A revision of the spider genera Herpyllus and Scotophaeus (Araneae, Gnaphosidae) in North America. Bulletin of the American Museum of Natural History 159:1-44.

1980a. A revision of the North American spider genera Nodocion, Litopyllus, and Synaphosus (Araneae, 
ApPEndix 2. Continued.

Gnaphosidae). American Museum Novitates 2691: $1-26$.

1980b. A revision of the spider genus Cesonia (Araneae, Gnaphosidae). Bulletin of the American Museum of Natural History 165:335-386.

. 1982. A revision of the American spiders of the genus Drassyllus (Araneae, Gnaphosidae). Bulletin of the American Museum of Natural History 173:1-97.

1983. A revision of the American spiders of the genus Zelotes (Araneae, Gnaphosidae). Bulletin of the American Museum of Natural History 174:97-192. 1988. A revision of the American spiders of the genus Micaria (Araneae, Gnaphosidae). American Museum Novitates 2916:1-64.

Richman, D.B., D.C. Lightfoot, C.A. Sutherland, and D.J. Ferguson. 1993. A manual of the grasshoppers of New Mexico. Handbook No. 7, Cooperative Extension Service, New Mexico State University, Las Cruces. 112 pp.
APPENDix 2. Continued.

Sauer, R.J., and N.I. Platnick. 1972. The crab spider genus Ebo (Araneida: Thomisidae) in the United States and Canada. Canadian Entomologist 104:35-60. Vetter, R.S. 2001. Revision of the spider genus Neoanagraphis (Araneae, Liocranidae). Journal of Arachnology 29:1-10.

VogeL, B.R. 1964. A taxonomic revision of the distincta group of the wolf-spider genus Pardosa in America north of Mexico (Araneida, Lycosidae). Postilla $82: 1-30$.

2004. A review of the spider genera Pardosa and Acantholycosa (Araneae, Lycosidae) of the 48 contiguous United States. Journal of Arachnology 32:55-108.

WALLACE, H.K. 1942. A revision of the burrowing spiders of the genus Geolycosa (Araneae, Lycosidae). American Midland Naturalist 27:1-62. 